\title{
Impact of COVID-19 \& Economic Outlook for Small Business - A Survey Based Study
}

\author{
Prashanth Ramachandra ${ }^{1}$, Jaclyn Han ${ }^{1}$, and Johnny Kent ${ }^{1}$ \\ ${ }^{1}$ William Fremd High School, Palatine, IL, USA
}

\section{ABSTRACT}

The unprecedented challenges from the Covid-19 pandemic not only continue to be a major public health concern, but also impose serious economic uncertainty on small businesses across the nation. To assess how small businesses ${ }^{2}$ were impacted in the first half of 2020 and gauge their economic outlook for the second half of 2020, I conducted an original survey of 86 companies. The results reveal several important metrics. First, $40 \%$ of surveyed companies drastically reduced operations for a duration of 1 to 2 months in first half of 2020, with most resorting to reduction of hours, furloughs, and/or layoffs. Second, 75\% of companies sought Paycheck Protection Program (PPP) loans, and every company that applied for PPP received approval. Third, $30 \%$ of companies forecast a decrease in revenue and reduction in staffing in the second half of 2020. Fourth, a trend of delayed receivables and increased expenses due to Covid19 becomes evident. Fifth, businesses overwhelmingly report an imminent need for a second stimulus relief from Congress to stabilize their operations and to avoid reductions in employment.

\section{Introduction}

On January $9^{\text {th, }}$ 2020, the World Health Organization (WHO) announced that there was a mysterious coronavirusrelated pneumonia (COVID-19) in Wuhan, China. At that time, the WHO still had doubts about how serious the virus was. There were 59 confirmed cases, almost all of them in East Asia, and travel precautions were already being considered. Since then, the COVID-19 virus has evolved from an isolated disease in a region of China to a global pandemic that has killed hundreds of thousands of people worldwide, brought countries to a standstill, pushed hospital systems to the brink, and dragged the global economy into a recession. On January 21st, a Washington state resident becomes the first person in the United States with a confirmed case of the virus having returned from Wuhan on January 15th. On January 31st, with a worldwide death toll of more than 200 and nearly 10,000 cases, the WHO issued a Global Health Emergency. Human-to-human transmission was quickly spreading, and confirmed cases were reported in the United States, China, Germany, Japan, Vietnam, and Taiwan.

The month of March was when coronavirus exploded. The WHO declared a global pandemic on March 11th. Across the country, schools and colleges were closed and forced into remote learning. Restaurants, malls, and businesses were closed down, and travel restrictions were implemented nationally. Some of America's workforce began to work from home but millions lost their jobs. The COVID-19 outbreak and the economic downturn it engendered swelled the ranks of unemployed Americans by more than 14 million, from 6.2 million in February to 20.5 million in May 2020. As a result, the U.S. unemployment rate shot up from 3.8\% in February to 13.0\% in May (Department of Labor, 2020). By the month of May, over 100,000 people in the U.S. had died of COVID-19 (Center for Disease Control, 2020) In order to prop-up the economic environment, Congress passed a fiscal stimulus bill. One of the main cornerstones of this stimulus is the provision of financial aid to small businesses through the Paycheck Protection Program (PPP). The PPP is primarily intended to allow businesses, many of which lack access to credit in the economically strained environment, to maintain employment and wages. The PPP is structured as a guaranteed loan program through the Small Business Administration (SBA). Qualifying firms apply to a participating private lender; once the loan is approved by the SBA, the lender must quickly distribute the funds to the firm (Autor et. Al, 2020). The 
PPP has a significant provision that allows the loans to be forgivable if the proceeds from the loan are used only for employment and wages. As of June 30,2020, the SBA has approved over $\$ 521$ billion for PPP loans for nearly 4.8 million small businesses, which equates to an average loan size of about \$107,000 (Small Business Administration, 2020). Currently, near the end of September, the unemployment rate has recovered modestly and stands at 7\%. However, with nearly 300,000 deaths and 18 million total positive cases projected by the end of the year, businesses across the nation are facing unprecedented challenges.

Small businesses are the lifeblood of the U.S. economy: they create two-thirds of net new jobs and drive U.S. innovation and competition (Small Business Administration, December 2018). Small businesses in the USA, which account for $44 \%$ of U.S. economic activity, employ about 60 million people. Understanding the performance of small businesses can not only provide a clearer picture of the status of US economy, but it can also reveal leading indicators for forecasting where the economy is headed. To understand how Covid-19 has impacted small business in the first half of 2020, as well as to gauge expectations of small business leaders for the second half of 2020, I conducted a survey of companies from different industries across the nation. The focus of the survey was to (A) assess the operational impact of Covid-19 on small businesses, (B) identify small business owner's financial forecast for second half of 2020, and (C) understand the utilization of Paycheck Protection Program funding by small businesses. Appendix 1 displays the survey questions.

Analysis of the survey responses reveal widespread disruption of business activity in the first half of 2020. However, there is considerable variability in the extent of disruption among different industry sectors. Small businesses in the technology sector were not as severely disrupted as manufacturing or service sectors. Businesses are responding to Covid-19 by increasing work-from-home options, deploying personal protection equipment, and implementing social distancing practices. Business owners are not facing resistance to these practices from workers, which helps in maintaining workplace health and safety measures, a vital element for achieving economic growth.

This paper resembles Bartik (Bartik et Al., 2020) in the survey methodology used and the presentation of content. I build on their research by increasing representation of small businesses that have higher employee counts, are located in Midwest, and specialize in manufacturing and technology sectors. This paper also focuses on measuring perceptions about the future to help develop a basis for economic forecasts.

\section{Survey Details}

The survey was distributed by email to targeted small business owners through references from various chambers of commerce and clients of Insperity, one of the largest Professional Employment Organizations (PEO) serving companies nationwide. There were no sample selection criteria except that it should be a small business with under 500 employees. Michael Schnitzler, Account Manager at Insperity, helped with identifying who among the Insperity clients may be contacted and provided contact information. Emails with surveys were also sent to small business owners from the contact information provided by various chambers of commerce. Out of the 506 surveys that were sent out, 412 surveys were sent to Insperity clients, and 94 surveys were sent to members of various chambers of commerce. 86 complete responses were received that were used for analysis. The $17 \%$ conversion rate is comparable to the $10 \%$ to $15 \%$ conversion rate of similar surveys on this subject (Bartik et Al., 2020).

The survey consisted of 26 questions that covered three main areas: business information (such as size, sector, location), business performance with questions about outcomes in the first half of 2020, and business forecasts with questions about expectations for second half of 2020. The survey data was compared with US Business Firmographics June 2020 data published by The North American Industry Classification System (NAICS) and Small Business Administration Office of Advocacy data.

Table 1 and Figure 1 summarize the responses categorized by firm size. Relative to the size distribution of all U.S. firms as reported in the 2018 Small Business Profile by the U.S. Small Business Administration, small businesses with more employees are overrepresented and firms with fewer employees are underrepresented in the survey. Although this may limit the external validity of the study when making extrapolations for all small businesses, the 
higher representation of larger employee sizes in the survey provides insight on the effects of Covid-19 on small businesses that have more than 10 employees. This insight could be valuable for assessing the macro economic effects of Covid-19 on small businesses.

Table 1. Business Size in the survey and US Business

\begin{tabular}{|c|c|c|c|}
\hline Employee Count & Survey Count & Survey & US Business \\
\hline 10 or less & 9 & $10 \%$ & $87 \%$ \\
\hline $11-25$ & 22 & $26 \%$ & $6 \%$ \\
\hline $26-50$ & 8 & $9 \%$ & $4 \%$ \\
\hline $51-100$ & 17 & $20 \%$ & $2 \%$ \\
\hline $101-200$ & 8 & $9 \%$ & $1 \%$ \\
\hline $201-500$ & 22 & $26 \%$ & $0 \%$ \\
\hline Total & 86 & $100 \%$ & $100 \%$ \\
\hline
\end{tabular}

\section{BUSINESS SIZE IN THE SURVEY AND US BUSINESS}

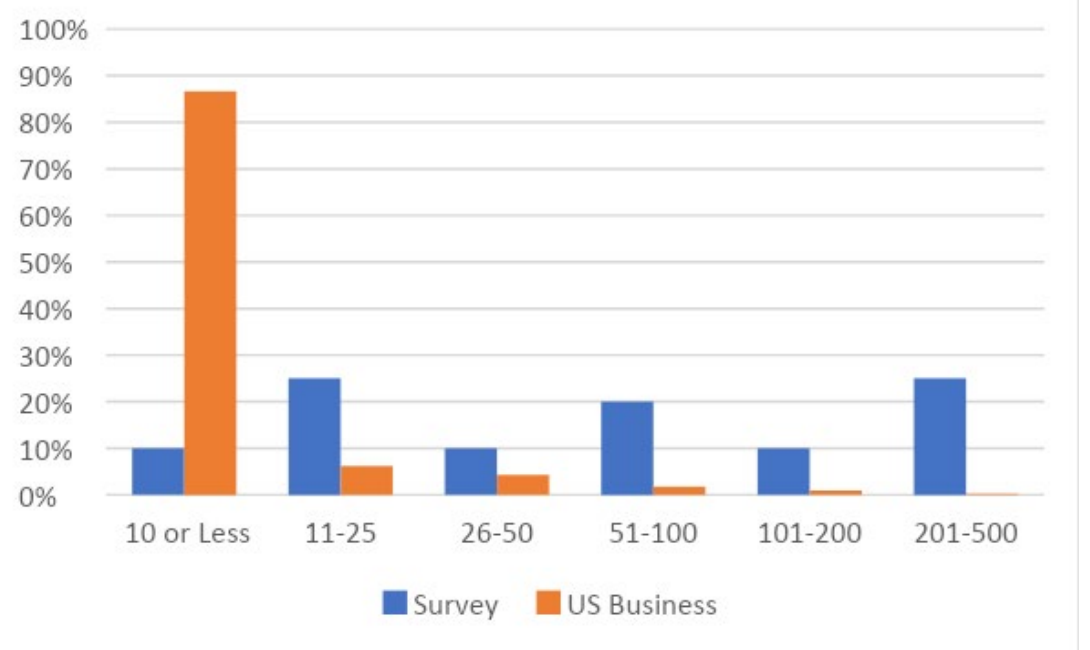

Figure 1 - Business Size

Figure 2 shows the distribution of survey responses by five geographic locations: North East, South East, Midwest, North West, and South West. Firms from the Midwest representation are notably overrepresented in the survey, comprising $59 \%$ of survey respondents versus $20 \%$ of all US firms. The primary focus of this research paper is thus on firms from the Midwest, which was underrepresented in similar published research (Bartik et Al., 2020). Although this may limit my ability to extrapolate the data nationally, the representation of all regions in the survey provides a suggestive basis for further study.

Table 2. Business Location in the Survey and US Business

\begin{tabular}{|c|c|c|c|}
\hline Geographic Location & Survey Count & Survey & US Business \\
\hline North East & 9 & $10 \%$ & $23 \%$ \\
\hline South East & 11 & $13 \%$ & $30 \%$ \\
\hline Midwest & 51 & $59 \%$ & $20 \%$ \\
\hline North West & 4 & $5 \%$ & $9 \%$ \\
\hline South West & 11 & $13 \%$ & $18 \%$ \\
\hline
\end{tabular}




\begin{tabular}{|c|c|c|c|}
\hline Total & 86 & $100 \%$ & $100 \%$ \\
\hline
\end{tabular}

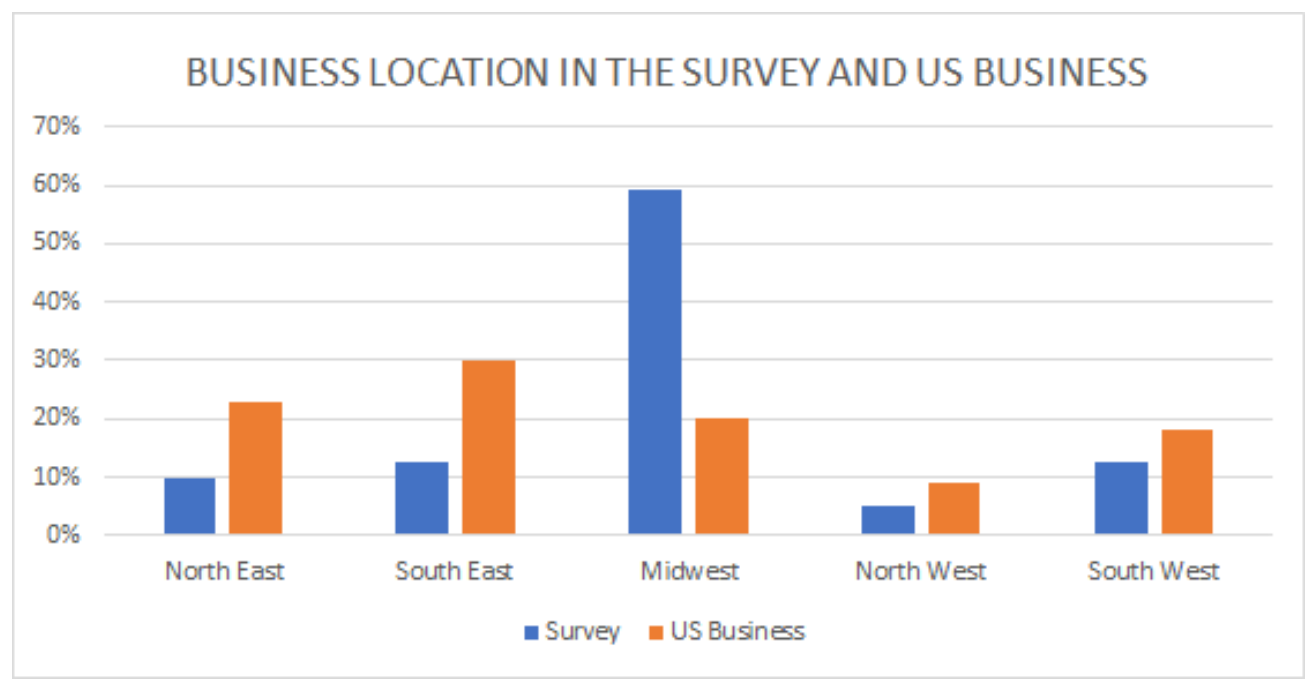

Figure 2 - Business Location

The responses covered a wide range of industrial sectors, as shown in Figure 3. Comparing the representation of industry sectors from the survey with the corresponding share of employment in those sectors published by the Small Business Administration (SBA) reveals that Manufacturing, Distribution, Technology, Consulting and Other sectors have higher representation levels in the survey, but also that Retail and Health and Education are not represented in the survey. Although this disparity in representation may limit the extrapolation of the data across all sectors, valid observations and conclusions can be made from the data set for the well-represented sectors.

Table 3 - Industry Mix in the Survey and US Business

\begin{tabular}{|c|c|c|c|}
\hline Industry Sector & Survey Count & Survey & US Business \\
\hline Manufacturing & 13 & $15 \%$ & $7.3 \%$ \\
\hline Service & 17 & $20 \%$ & $61.1 \%$ \\
\hline Retail & 0 & $0 \%$ & $9.6 \%$ \\
\hline Distribution & 9 & $10 \%$ & $5.9 \%$ \\
\hline Technology & 22 & $26 \%$ & $1.7 \%$ \\
\hline Health & 0 & $0 \%$ & $8.5 \%$ \\
\hline Education & 0 & $0 \%$ & $2.5 \%$ \\
\hline Consulting & 4 & $5 \%$ & $0.3 \%$ \\
\hline Other & 21 & $24 \%$ & $3.1 \%$ \\
\hline Total & 86 & $100 \%$ & $100 \%$ \\
\hline
\end{tabular}




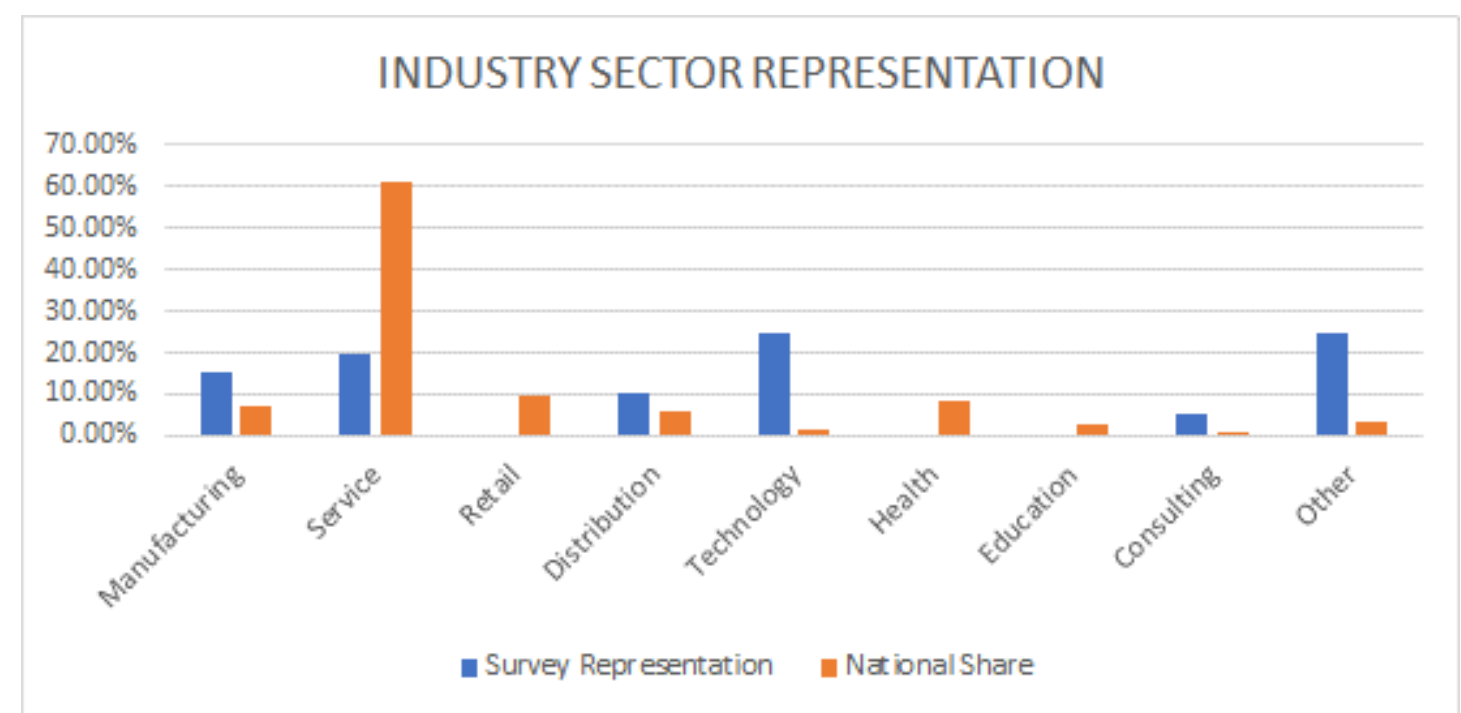

Figure 3 - Industry Mix

These caveats notwithstanding, the sample set provides representation of small businesses across the nation and allows me to study the impact of Covid-19 firms of various sizes, regions, and sectors. Although the sample size is not large, the qualitative information from the survey reveals widespread business disruptions and suggests a pressing need for additional policy relief.

\section{Business Results in the first half of 2020}

To assess the impact of Covid-19 on small businesses, the data from the survey was analyzed to answer three vital questions: how operations were impacted, how revenue was affected, and if businesses used PPP loans.

$40 \%$ of surveyed businesses reported experiencing a significant disruption in operations during the first half of 2020. The median duration of the reported disruption was 1-2 months. The data among companies that reported significant disruption shows the prevalence of disruption in all business sizes, ranging from companies with under 10 few employees to companies with over 200 employees. This highlights the wide-spread disruption on business activity from Covid-19. However, the data as shown in Figure 4 and Figure 5 reveals that there is considerable correlation in the disruption rate between the industry and geographic location. Half of the companies that reported significant disruption are from the manufacturing sector and nearly $62 \%$ of the companies that reported disruption are in the Midwest. It is noteworthy that none of the companies from the technology industry reported significant disruption and companies in the Southwest reported the least share of disruption.

Table 4 - Operation Disruption by Industry Sector

\begin{tabular}{|c|c|c|}
\hline Industry Sector & Survey Count & Survey \% \\
\hline Manufacturing & 17 & $50 \%$ \\
\hline Service & 9 & $26 \%$ \\
\hline Wholesale/Distribution & 5 & $15 \%$ \\
\hline Other & 3 & $9 \%$ \\
\hline Total & 34 & $100 \%$ \\
\hline
\end{tabular}




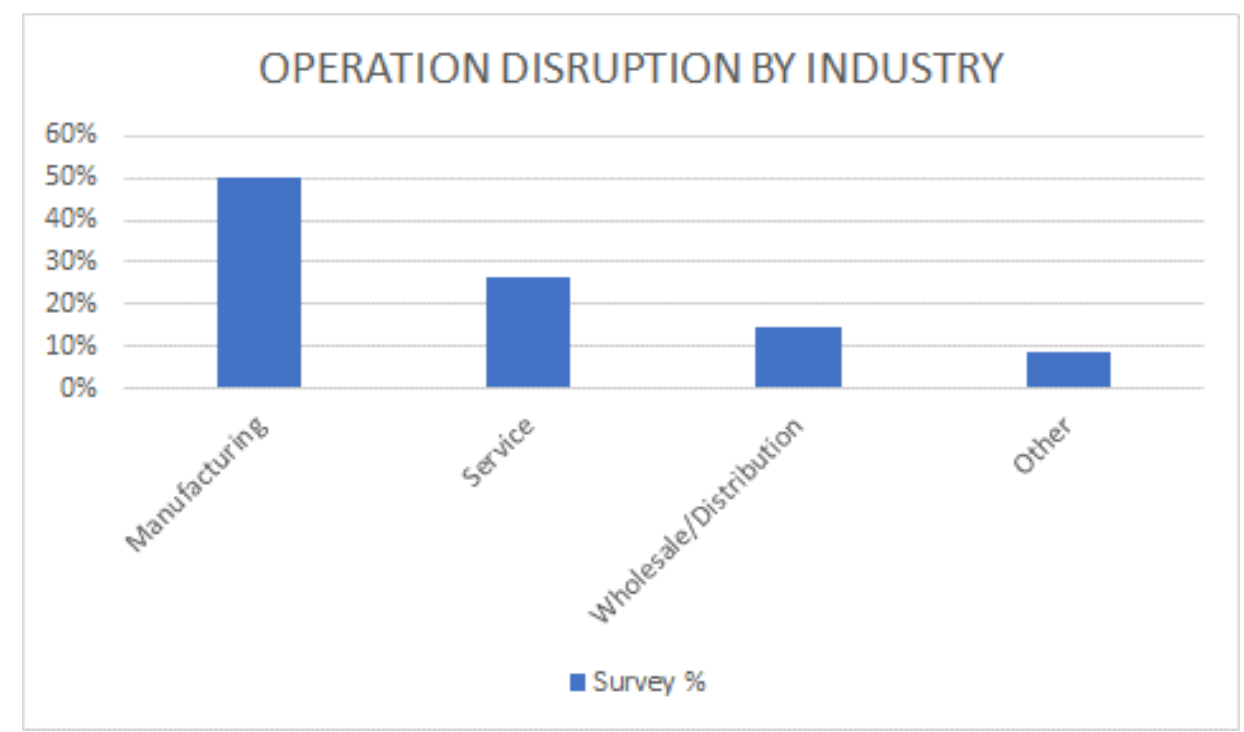

Figure 4 - Operation Disruption by Industry

Table 5 - Operation Disruption by Location

\begin{tabular}{|c|c|c|}
\hline Location & Survey Count & Survey \% \\
\hline Midwest & 21 & $62 \%$ \\
\hline North East & 5 & $15 \%$ \\
\hline South East & 4 & $12 \%$ \\
\hline North West & 3 & $9 \%$ \\
\hline South West & 1 & $3 \%$ \\
\hline Total & 34 & $100 \%$ \\
\hline
\end{tabular}

\section{OPERATION DISRUPTION BY LOCATION}

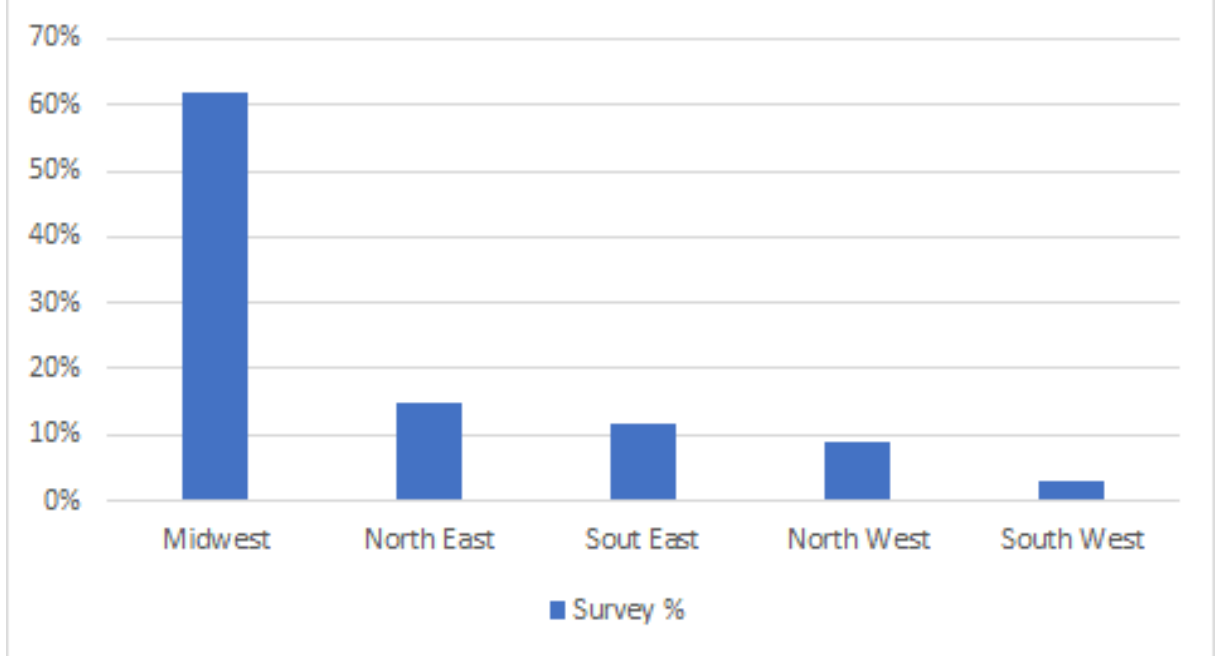

Figure 5 - Operation Disruption by Location

The survey data shows that all the companies that experienced significant reductions in operation also implemented changes in their staffing needs. The average duration for which the staffing needs were changed was 1-2 months, and these changes affected about $1 / 3$ of the employees in those companies. It is noteworthy that companies that did not 
experience disruptions in operations also did not implement any staffing changes, implying that companies were not preemptively making reductions in staffing due to Covid-19. Among the companies that implemented staff reductions, $75 \%$ took only short-term measures such as reduction of hours or furlough, implying that most business owners felt that the disruption to the operation was temporary and would not have long-term effects. Figure 6 summarizes this data. The survey data also revealed that companies are embracing work-from-home options (WFH) due to Covid-19. An astonishing $85 \%$ of the companies reported implementing or increasing WFH options in the first half of 2020. It can be argued that without such a significant increase in WFH options, the share of companies reporting significant disruption would have been higher. This underscores the increasing role of technology in workplaces and how widespread WFH usage can influence the workplace eco-systems such as commercial office space construction/occupancy, business travel/hospitality etc.

Table 6 - Staff Reduction

\begin{tabular}{|c|c|c|}
\hline Staff Reduction & Survey Count & Survey \% \\
\hline Reduction of Hours & 5 & $15 \%$ \\
\hline Furlough & 16 & $47 \%$ \\
\hline Layoff & 11 & $32 \%$ \\
\hline Permanent Reduction & 2 & $6 \%$ \\
\hline Total & 34 & $100 \%$ \\
\hline
\end{tabular}

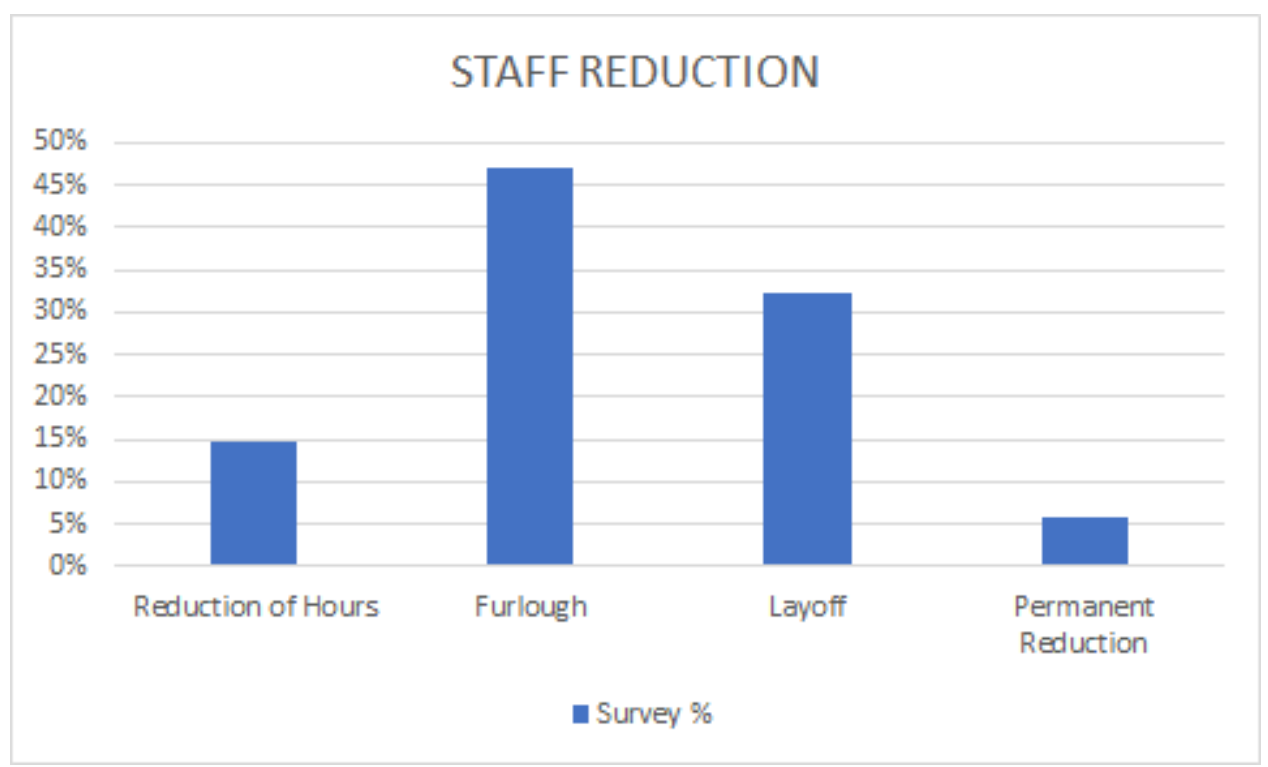

Figure 6 - Staff Reduction

Figure 7 shows that there is widespread impact of Covid- 19 on overall business revenue in the first half of $2020.60 \%$ of the companies reported a decrease in revenue in first half of 2020 compared to the same period in 2019. It is noteworthy that although only $40 \%$ of the companies reported a significant reduction in operations, the revenue reduction has affected a large share of companies. 
Table 7 - Revenue Impact

\begin{tabular}{|c|c|c|}
\hline Revenue Change & Survey Count & Survey \% \\
\hline Decrease & 51 & $59 \%$ \\
\hline Increase & 17 & $10 \%$ \\
\hline Did Not Change & 9 & $10 \%$ \\
\hline Do Not Know & 9 & $100 \%$ \\
\hline Total & 86 & $10 \%$ \\
\hline
\end{tabular}

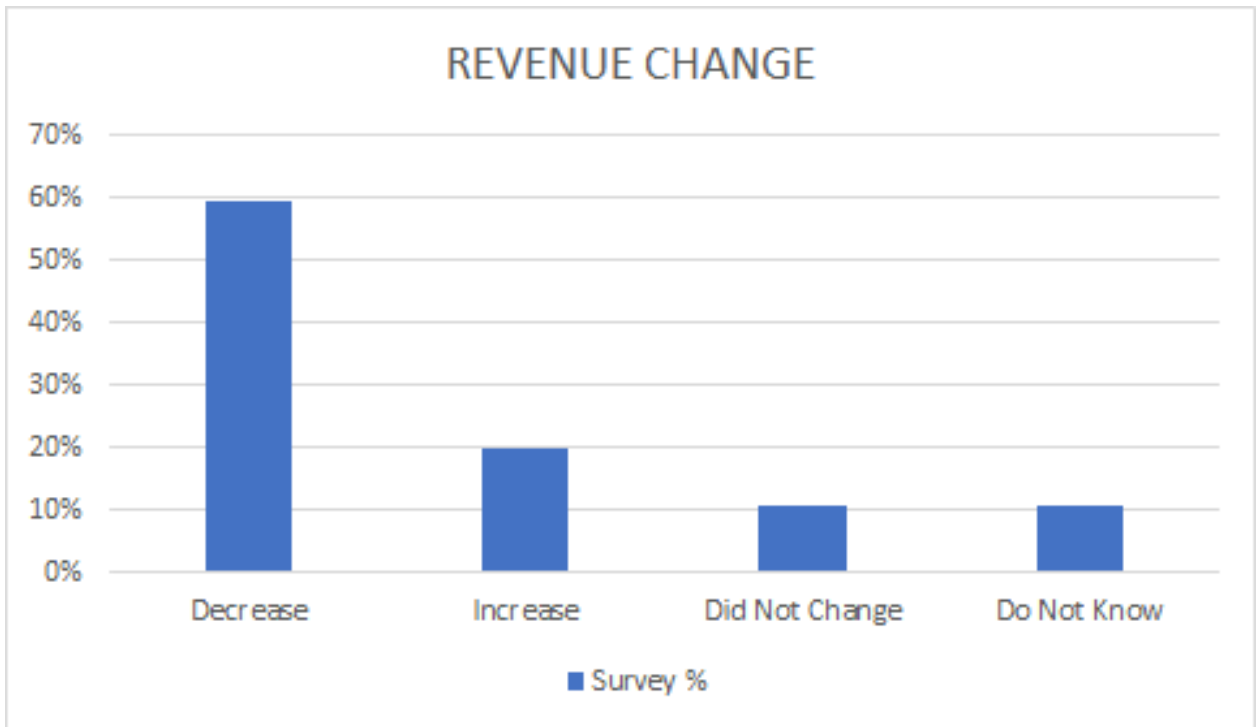

Figure 7 - Revenue Change

Businesses are also facing delay in collecting their receivables. As shown in Figure 8, 60\% of businesses are experiencing delays in receivables collection. The compounding pressure that businesses face from revenue reduction and receivables collection delays can cause cash flow issues within businesses.

Table 8 - Receivables Collection

\begin{tabular}{|c|c|c|}
\hline Receivables Collection & Survey Count & Survey \% \\
\hline On Time & 26 & $30 \%$ \\
\hline Delayed -0 - 10 days & 4 & $5 \%$ \\
\hline Delayed 11 - 20 days & 13 & $40 \%$ \\
\hline Delayed > 20 days & 34 & $10 \%$ \\
\hline Do Not Know & 9 & $100 \%$ \\
\hline Total & 86 & \\
\hline
\end{tabular}




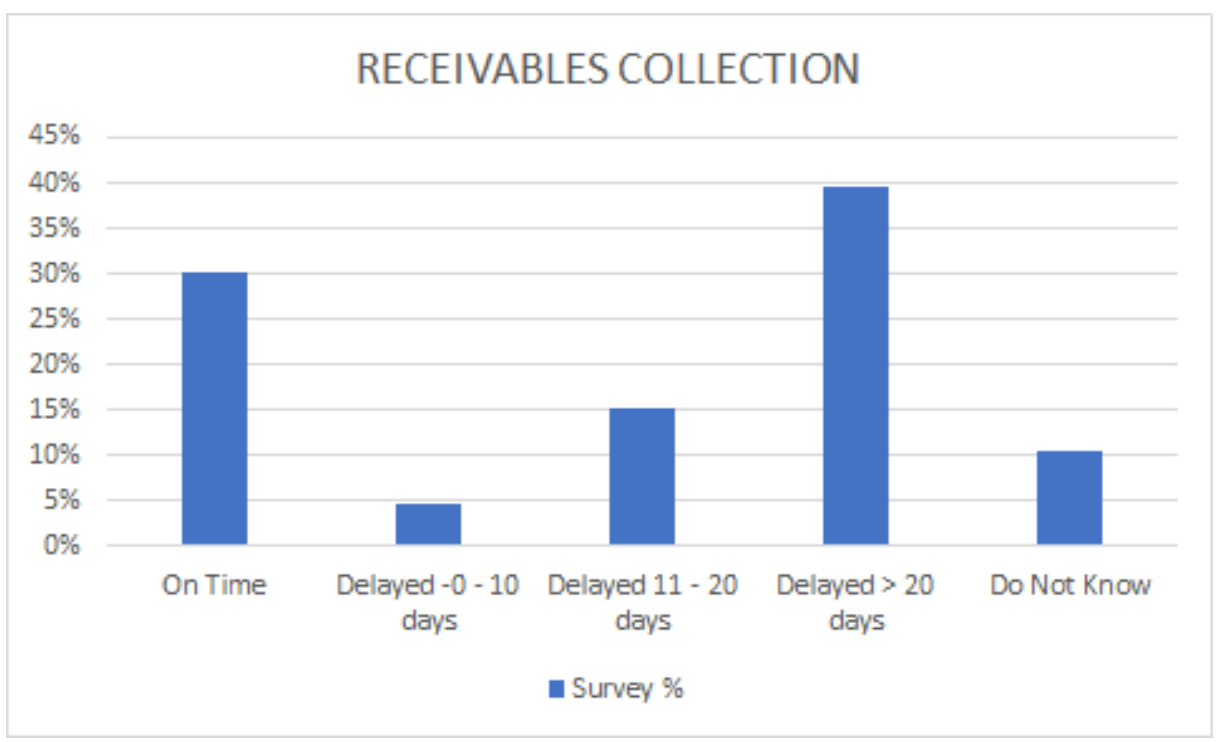

Figure 8 - Receivables Collection

Data from the survey show that most companies applied for and received a Paycheck Protection Program (PPP) loan. Figure 9 summarizes this data. $75 \%$ of the companies surveyed applied for a PPP loan, and $100 \%$ of the companies that applied for a loan received approval. It is highly likely that funding from the PPP would have alleviated the cash availability issue discussed earlier. It is noteworthy that the share of companies in the survey that received approved for the loan is higher than the share of companies that reported disruption in operation and reduction in revenue in the first half of 2020. This suggests that those companies may be better positioned financially than they would have without the PPP funding.

Table 9 - PPP Loan Application

\begin{tabular}{|c|c|c|c|c|}
\hline PPP Loan & Survey Count & Survey \% & US Count & US Business \% \\
\hline Received & 64 & $74 \%$ & $4,888,388$ & $89 \%$ \\
\hline Not Received & 22 & $26 \%$ & 611,612 & $11 \%$ \\
\hline Total & 86 & $100 \%$ & $5,500,000$ & $100 \%$ \\
\hline
\end{tabular}

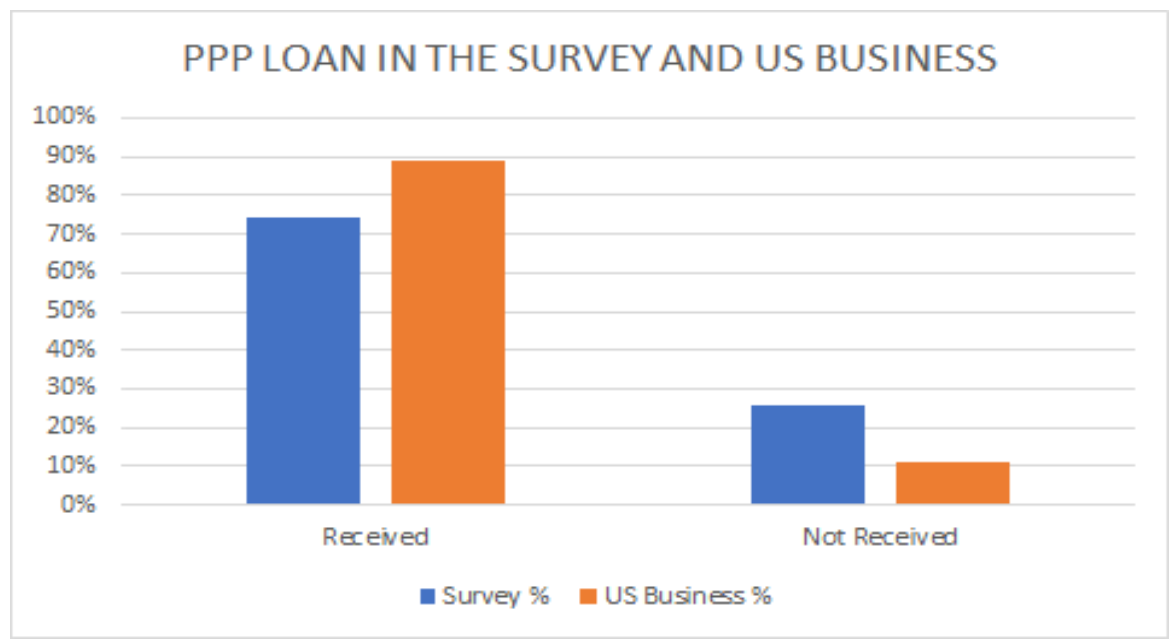

Figure 9 - PPP Loan 


\section{Business Forecast for the second half of 2020.}

As the focus shifts from the business environment in the first half of 2020 to expectations in the second half of 2020, there are both encouraging signs and troubling trends. Figure 10 summarizes this data. On the top-line revenue forecast, in general, are significant signs of optimism among businesses. $45 \%$ of surveyed businesses expect revenue to increase in the second half of 2020, which is more than double the $\%$ of companies that experienced an increase in revenue in the first half of 2020. Similarly, 30\% of the companies expect revenue to decrease in the second half of 2020 , which is half of the $\%$ of companies that experienced decreases in revenue in the first half of 2020 .

Table 10 - Revenue \& Staffing Forecast

\begin{tabular}{|c|c|c|c|c|}
\hline Forecast & Revenue Count & Revenue & Staffing Count & Staffing \\
\hline Decrease & 26 & $30 \%$ & 26 & $30 \%$ \\
\hline Increase & 39 & $45 \%$ & 17 & $20 \%$ \\
\hline Does Not Change & 9 & $10 \%$ & 39 & $45 \%$ \\
\hline Do Not Know & 12 & $14 \%$ & 4 & $5 \%$ \\
\hline Total & 86 & $100 \%$ & 86 & $100 \%$ \\
\hline
\end{tabular}

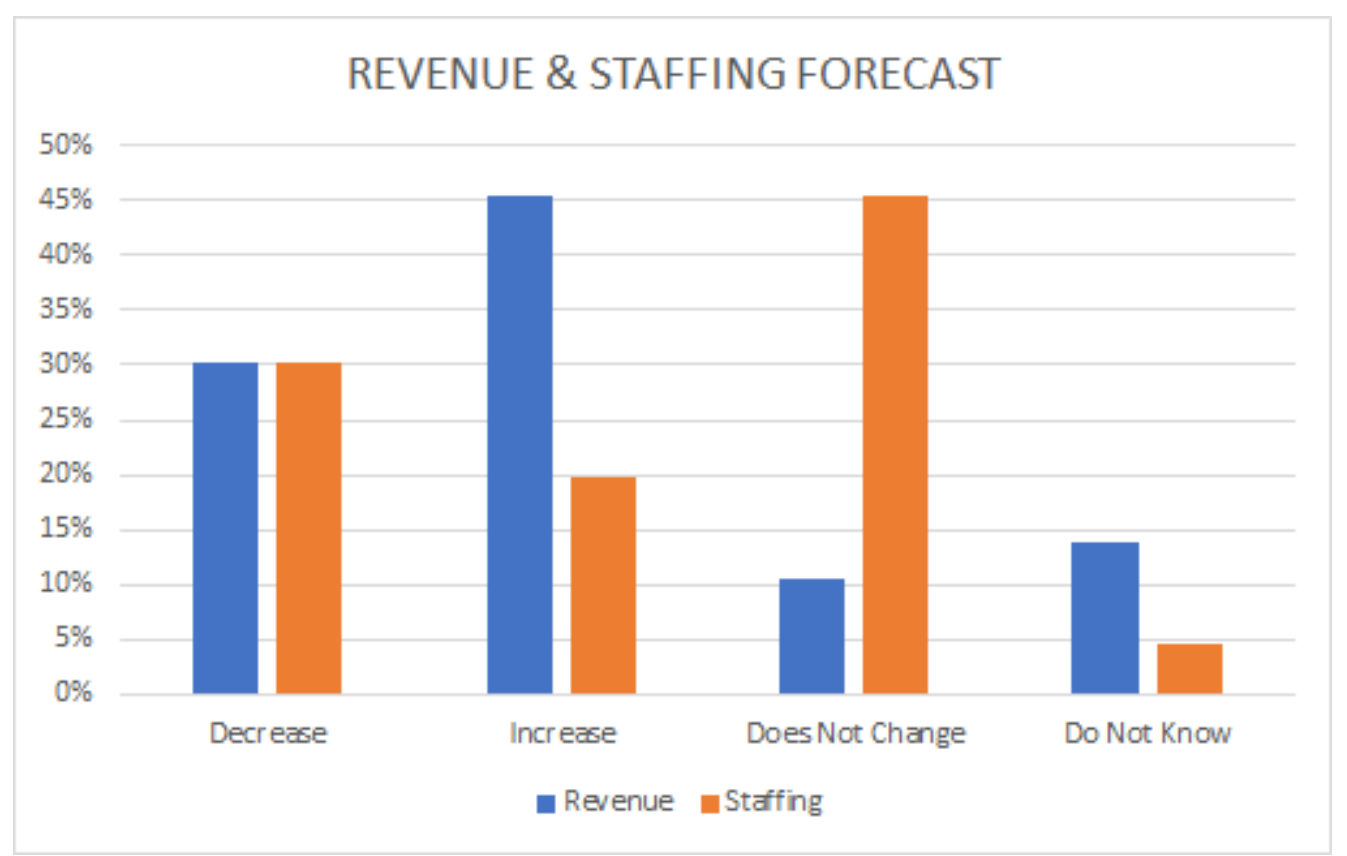

Figure 10 - Revenue \& Staffing Forecast

As shown in Figure 10, about $20 \%$ of firms plan to increase the staffing and $45 \%$ of the companies do not plan on making changes in the second half of 2020. Similarly, 30\% of the companies plan on decreasing their staffing in the second half of 2020 compared to the $40 \%$ of the companies who reduced staffing in the first half of 2020 .

Analyzing the survey data for revenue and staffing forecasts by industry sector and geographic location sheds further light on the economic environment. Figure 11 summarizes the data for revenue forecast by sector. 
Table 11 - Revenue Forecast by Industry Sector

\begin{tabular}{|c|c|c|c|c|}
\hline Revenue Forecast/Sector & Decrease & Increase & No Change & Do Not Know \\
\hline Manufacturing & 4 & 15 & 0 & 0 \\
\hline Service & 8 & 8 & 0 & 4 \\
\hline Wholesale/Distribution & 0 & 4 & 0 & 4 \\
\hline Technology & 4 & 0 & 8 & 0 \\
\hline Consulting & 0 & 4 & 0 & \\
\hline Other & 4 & 15 & 0 & \\
\hline
\end{tabular}

\begin{tabular}{|c|c|c|c|c|}
\hline Revenue Forecast & Decrease & Increase & No Change & Do Not Know \\
\hline Manufacturing & $5 \%$ & $17 \%$ & $0 \%$ & $0 \%$ \\
\hline Service & $9 \%$ & $9 \%$ & $0 \%$ & $5 \%$ \\
\hline Wholesale/Distribution & $0 \%$ & $5 \%$ & $0 \%$ & $0 \%$ \\
\hline Technology & $5 \%$ & $0 \%$ & $9 \%$ & $5 \%$ \\
\hline Consulting & $0 \%$ & $5 \%$ & $0 \%$ & $0 \%$ \\
\hline Other & $5 \%$ & $17 \%$ & $0 \%$ & $5 \%$ \\
\hline
\end{tabular}

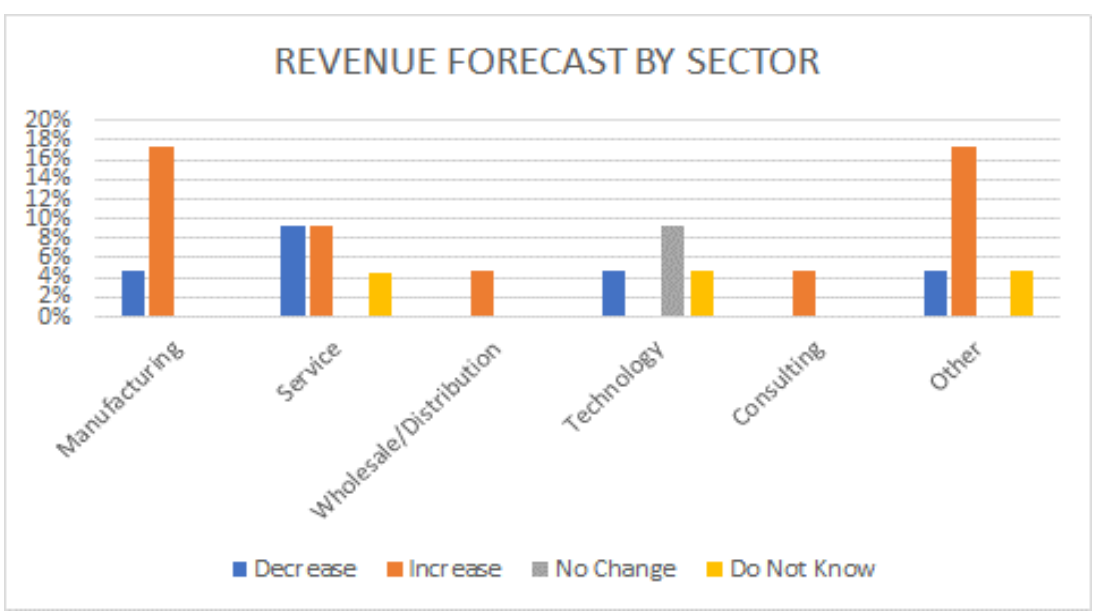

Figure 11 - Revenue Forecast by Sector

Approximately $18 \%$ of manufacturing firms forecast increases in revenue in the second half of 2020 . This is in striking contrast to the first half of 2020, when manufacturing companies showed the most disruption. The service sector presents an unclear picture, with an equal share of companies in the sector projecting a decrease or increase in revenue. Nearly twice as many companies in the technology sector report no change in revenue compared to technology companies forecasting a decrease in revenue.

The survey data for revenue forecasts by geographic location reveal an uneven economic environment. Figure 12 summarizes this data.

Table 12 - Revenue Forecast by Location

\begin{tabular}{|c|c|c|c|c|}
\hline Revenue Forecast/Location & Decrease & Increase & No Change & Do Not Know \\
\hline Midwest & 18 & 24 & 0 & 7 \\
\hline North East & 4 & 0 & 4 & 0 \\
\hline South East & 7 & 10 & 4 & 0 \\
\hline North West & 0 & 0 & 0 & 4 \\
\hline
\end{tabular}




\begin{tabular}{|c|c|c|c|c|}
\hline South West & 0 & 0 & 4 & 0 \\
\hline
\end{tabular}

\begin{tabular}{|c|c|c|c|c|}
\hline Revenue Forecast & Decrease & Increase & No Change & Do Not Know \\
\hline Midwest & $21 \%$ & $28 \%$ & $0 \%$ & $8 \%$ \\
\hline North East & $5 \%$ & $0 \%$ & $5 \%$ & $0 \%$ \\
\hline South East & $8 \%$ & $12 \%$ & $5 \%$ & $0 \%$ \\
\hline North West & $0 \%$ & $0 \%$ & $0 \%$ & $5 \%$ \\
\hline South West & $0 \%$ & $0 \%$ & $5 \%$ & $0 \%$ \\
\hline
\end{tabular}

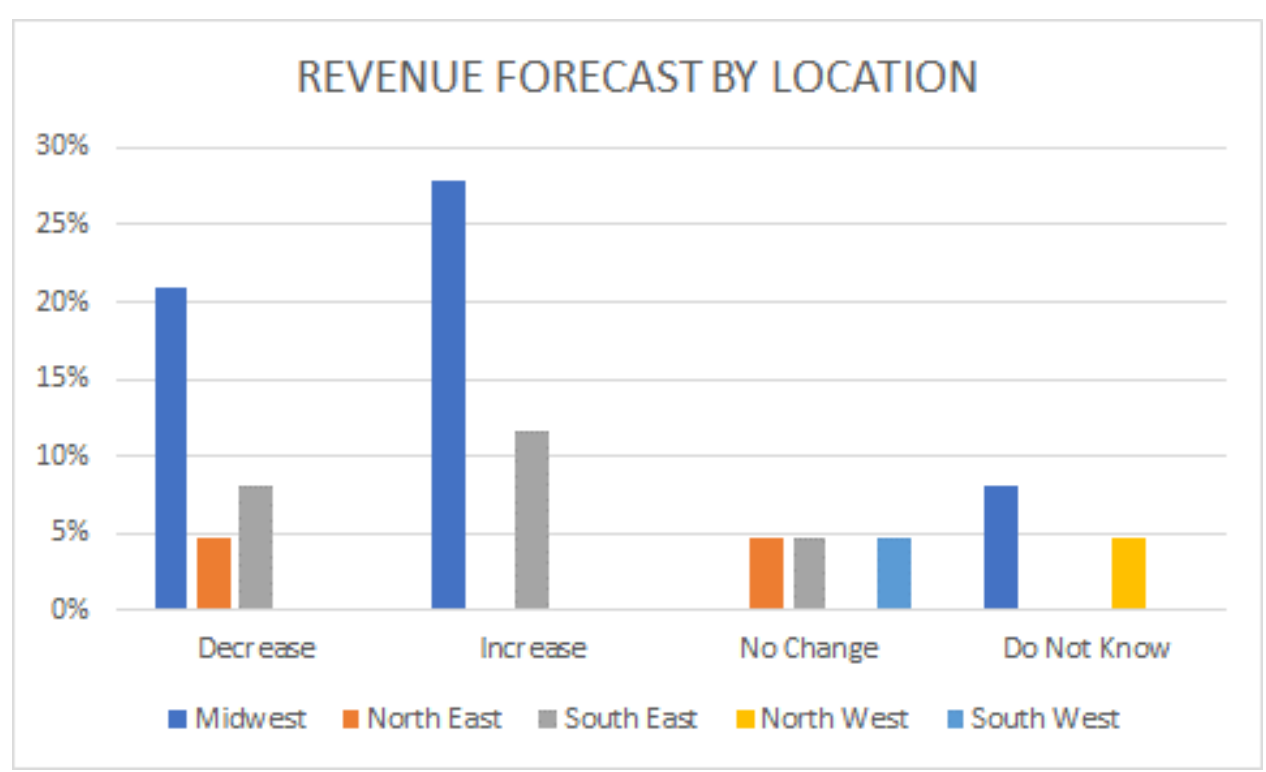

Figure 12 - Revenue Forecast by Location

Approximately 29\% of Midwestern firms forecast increases in revenue in the second half of 2020. This is in striking contrast to the first half of 2020, when companies located in the Midwest showed the most disruption. As shown in Figure 12, companies located in the Midwest and in the South East report a higher share of companies forecasting a revenue increase versus a revenue decrease, but in the North East, there is an equal share of companies forecasting a decrease or increase in revenue. The overall revenue trend presents modestly optimistic expectations by small business owners for the second half of 2020.

Reviewing the data for the staffing forecast as depicted in Figure 13 shows that companies in all sectors except for those categorized as Other do not plan on increasing the staffing levels in the second half of 2020.

Table 13 - Staffing Forecast by Industry Sector

\begin{tabular}{|c|c|c|c|c|}
\hline Staffing Forecast/Sector & Decrease & Increase & No Change & Do Not Know \\
\hline Manufacturing & 4 & 0 & 17 & 0 \\
\hline Service & 9 & 0 & 0 & 4 \\
\hline Wholesale/Distribution & 0 & 0 & 4 & 0 \\
\hline Technology & 0 & 0 & 17 & 0 \\
\hline Consulting & 0 & 0 & 4 & 0 \\
\hline Other & 4 & 14 & 9 & \\
\hline
\end{tabular}




\begin{tabular}{|c|c|c|c|c|}
\hline Staffing Forecast & Decrease & Increase & No Change & Do Not Know \\
\hline Manufacturing & $5 \%$ & $0 \%$ & $20 \%$ & $0 \%$ \\
\hline Service & $10 \%$ & $0 \%$ & $0 \%$ & $5 \%$ \\
\hline Wholesale/Distribution & $0 \%$ & $0 \%$ & $5 \%$ & $0 \%$ \\
\hline Technology & $0 \%$ & $0 \%$ & $20 \%$ & $0 \%$ \\
\hline Consulting & $0 \%$ & $0 \%$ & $5 \%$ & $0 \%$ \\
\hline Other & $5 \%$ & $16 \%$ & $10 \%$ & $0 \%$ \\
\hline
\end{tabular}

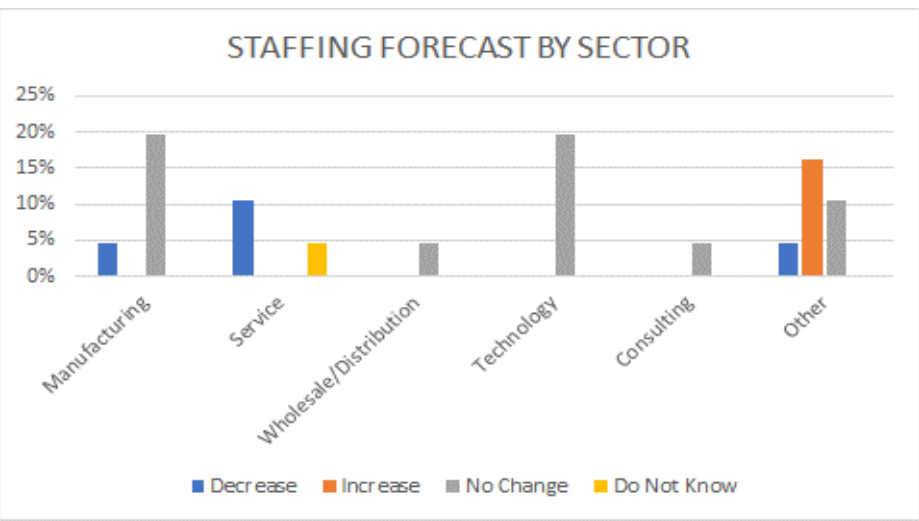

Figure 13 - Staffing Forecast by Sector

The above data reflects that even though revenue trends are encouraging, businesses may still be reluctant to hire. Staffing forecast by geographic location show that except for the Midwest and North West, where there is a modest share of companies forecasting an increase in staffing, other locations are not forecasting an increase in staffing.

Table 14 - Staffing Forecast by Location

\begin{tabular}{|c|c|c|c|c|}
\hline Staffing Forecast/Location & Decrease & Increase & No Change & Do Not Know \\
\hline Midwest & 12 & 8 & 34 & 4 \\
\hline North East & 4 & 0 & 4 & 0 \\
\hline South East & 8 & 0 & 4 & 0 \\
\hline North West & 0 & 4 & 0 & 0 \\
\hline South West & 0 & 0 & 4 & 0 \\
\hline
\end{tabular}

\begin{tabular}{|c|c|c|c|c|}
\hline Staffing Forecast & Decrease & Increase & No Change & Do Not Know \\
\hline Midwest & $14 \%$ & $9 \%$ & $40 \%$ & $5 \%$ \\
\hline North East & $5 \%$ & $0 \%$ & $5 \%$ & $0 \%$ \\
\hline South East & $9 \%$ & $0 \%$ & $5 \%$ & $0 \%$ \\
\hline North West & $0 \%$ & $5 \%$ & $0 \%$ & $0 \%$ \\
\hline South West & $0 \%$ & $0 \%$ & $5 \%$ & $0 \%$ \\
\hline
\end{tabular}




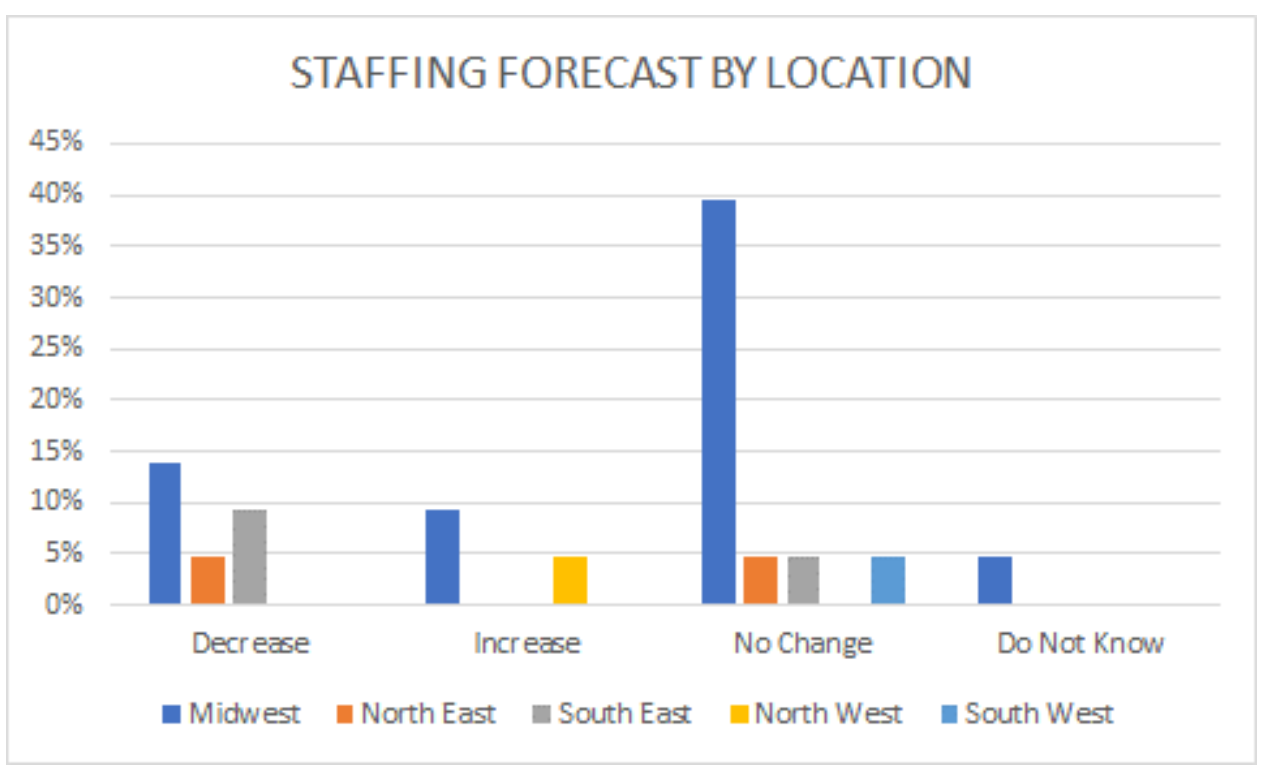

Figure 14 - Staffing Forecast by Location

This highlights that even though companies are generally forecasting an increase in revenue in second half, they are reluctant to increase staffing levels. This suggests that companies lack confidence in the strength of the recovery and therefore not willing to add fixed costs from additional payroll. This is understandable considering the ongoing uncertainty with the health risks posed by Covid-19.

The expense forecast by businesses presents a challenging environment. Figure 15 summarizes this data. $6 \%$ of the businesses surveyed are forecasting increased expenses due to Covid-19.

Table 15 - Expenses Forecast

\begin{tabular}{|c|c|c|}
\hline Expenses & Survey Count & Survey \% \\
\hline No Change & 26 & $30 \%$ \\
\hline Increase by 0 to $10 \%$ & 47 & $55 \%$ \\
\hline Increase by 11 to $20 \%$ & 4 & $5 \%$ \\
\hline Increase $>20 \%$ & 0 & $0 \%$ \\
\hline Do Not Know & 9 & $10 \%$ \\
\hline Total & 86 & $100 \%$ \\
\hline
\end{tabular}

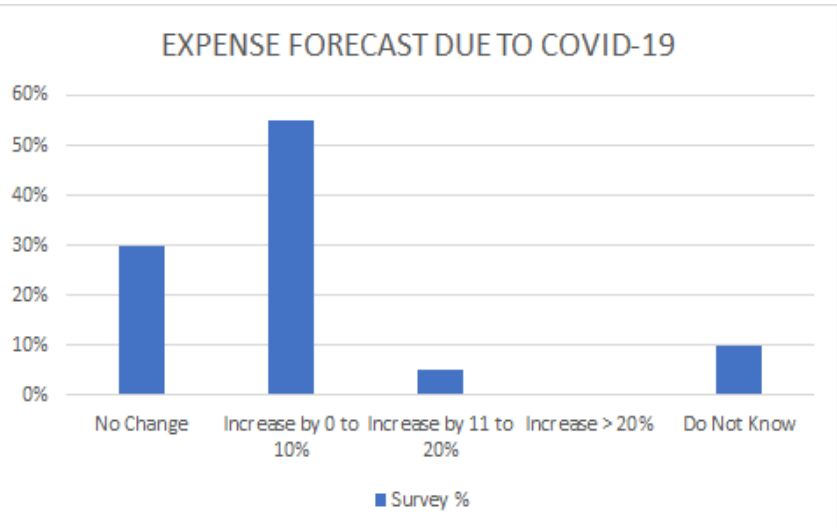

Figure 15 - Expense due to Covid-19 
This demonstrates that businesses are not only facing top line revenue challenges but also profitability pressures. $100 \%$ of the businesses surveyed reported using Personal Protection Equipment (PPE) and implementing social distancing in the workplace. It can be estimated that businesses also periodically perform disinfecting, cleaning, and other measures that could add to the cost burden. The survey also reveals that business owners almost unanimously report employees being supportive in implementing PPE and social distancing measures. This is very encouraging information and allows business owners to mitigate the risks of Covid-19 in their operations.

The survey data also reveals that an overwhelming number of respondents are supportive of Congressional proposals to pass a second round of fiscal stimulus that includes measures like the PPP loan.

Table 16 - Need for New Stimulus Plan

\begin{tabular}{|c|c|c|}
\hline Additional Stimulus & Survey Count & Survey \% \\
\hline Yes & 56 & $65 \%$ \\
\hline No & 30 & $35 \%$ \\
\hline Total & 86 & 100 \\
\hline
\end{tabular}

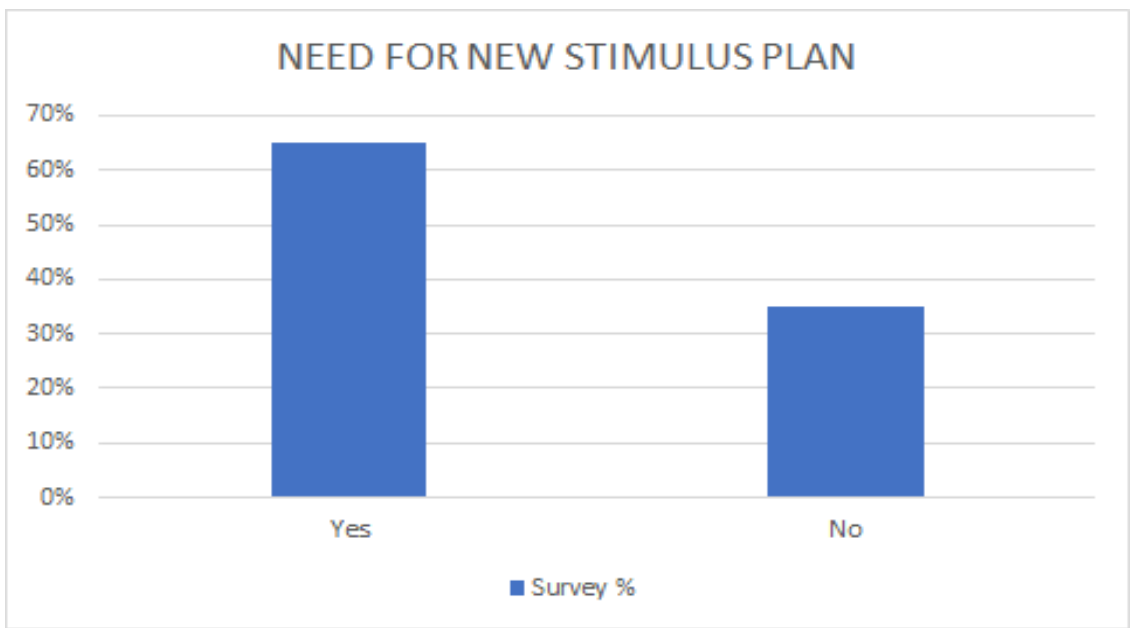

Figure 16 - Need for New Stimulus Plan

Figure 16 summarizes this data. This may be driven by their inability to support new hiring and/or bring back staff that were let go in the first half of 2020 due to lower profitability that companies were facing.

The survey also reveals that without additional stimulus funding, many businesses forecast reductions staffing in the second half of 2020. Figure 17 summarizes this data.

Table 17 - Staffing w/o New Stimulus Funding

\begin{tabular}{|c|c|c|}
\hline Staffing w/o Additional Stimulus & Survey Count & Survey \% \\
\hline Reduction of Hours & 26 & $30 \%$ \\
\hline Furlough & 17 & $20 \%$ \\
\hline Layoff & 0 & $0 \%$ \\
\hline Permanent Reduction & 26 & $30 \%$ \\
\hline No Change & 17 & $20 \%$ \\
\hline Total & 86 & $100 \%$ \\
\hline
\end{tabular}




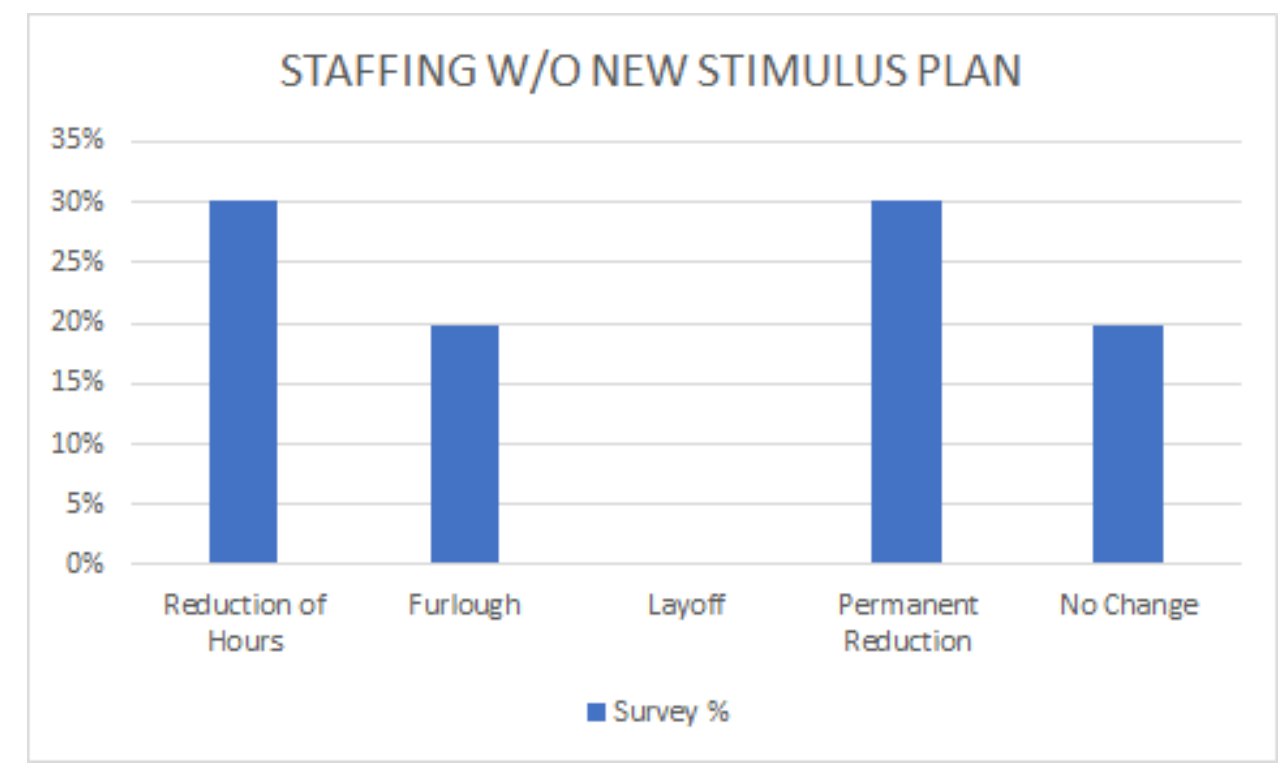

Figure 17 - Staffing w/o Stimulus Funding.

It is startling to see that $30 \%$ of the companies might consider permanent reduction of hours as opposed to a shortterm staff reduction, such as working fewer hours reported by $30 \%$ of the companies and furlough reported by $20 \%$ of the companies. It is noteworthy that only $10 \%$ of surveyed companies will maintain current staffing levels even if the Congress does not pass a new stimulus plan. There is some ambiguity on the effects of PPP funding pertaining to lowering the unemployment rate. Some estimates predict that the PPP funding does not have a measurable effect on lowering unemployment (Chetty et. $\mathrm{Al}, 2020)$ if the underlying public health issue is unresolved. Other research suggests that PPP loans have helped reduce the national unemployment rate up to $4.5 \%$ (Autor et. Al, 2020). The survey results provide evidence to support the claim that additional PPP funding to small business can have a positive impact on reducing unemployment rate.

\section{Conclusions}

Small businesses constitute a major force in the U.S economy. The results from the survey highlight the distress that small businesses are facing from the Covid-19 pandemic. Although the sample size in this paper is a fraction of the sample size used in the reference paper (Bartik et Al., 2020), the results are broadly similar, lending further credence to the results. The data shows that $40 \%$ of the surveyed companies have experienced drastic reductions in operations for 1 to 2 months in the first half of 2020, and all those affected companies took measures to reduce staffing levels. The manufacturing sector and companies located in the Midwest represent the largest share of businesses that reported significant disruption at $50 \%$ and $60 \%$ respectively. This may be skewed due to underrepresentation of retail and travel/hospitality sectors in the survey results. Businesses not only faced top line revenue challenges, but also confronted receivables delays and higher expenses resulting in cash flow issues and profit erosion. The widespread use of Paycheck Protection Program (PPP) by 75\% cent of the companies surveyed underscores that businesses may have avoided drastic effects, such as bankruptcy or defaulting on loans, with the help of this funding. Although the survey did not establish a causal connection between the companies that received PPP funding to their staffing levels or financial performance, it can be argued that without the funding, businesses may have considered cutting back on staffing levels, thereby leading to higher unemployment levels.

The staffing level estimates for the second half of 2020 shows 30\% of the companies plan on decreasing staffing level and $45 \%$ of the companies do not plan to increase the staffing level. This may be related to depletion of cash reserves from PPP funding and a lack of confidence in the economic environment. This suggests that the labor 
market conditions could weaken in the second half of 2020 and that unemployment levels could rise in the second half of 2020 .

$65 \%$ of the businesses support a second round of stimulus plans from Congress. The survey did not have responses from the economically hard-hit sectors like Travel \& Hospitality. If these sectors were to be represented in the survey it is highly likely that the share of companies seeking economic assistance would be even higher. This further supports the need for a second stimulus plan.

Companies are confronting significant cash flow issues due to lower revenue, higher expenses, and supply chain disruptions. This could result in a credit crunch resulting in higher delinquencies, missed loan payments, need for higher line of credits and even bankruptcies for businesses. The Federal Reserve and Congress should consider the risks of credit deterioration in the development and implementation of the second stimulus plan. The survey results showed that $40 \%$ of the companies reported significant disruption, but $75 \%$ of the companies received PPP funding. This suggests that there is opportunity for the lenders to be more scrupulous in assuring the funds are provided to companies that maximize the effectiveness of the stimulus plan.

Future studies in this topic that are focused on measuring the effectiveness of the stimulus funding can help develop public policy recommendations as a guide for combating recessions. Additionally, the significant increase in work from home practices presents opportunities and threats to the workplace ecosystem. Collecting data and analyzing the impact of WFH can be greatly beneficial to quantify the socioeconomic impact.

\section{Acknowledgements}

I am grateful to Steve Gauss from the Palatine Chamber of Commerce in helping me with test marketing the survey. I think Michael Schnitzler from Insperity Inc for connecting me with business owners across the nation and helping with survey distribution. Mike Kayman, president of SVOF, and Mark Levit, president of LDS Industries, provided valuable feedback on survey development. Patrick Kennedy, PhD student in the Economics Department at University of California Berkeley, and Mr. Johnny Kent from Fremd High School have been instrumental in guiding me with this paper and reviewing it.

\section{References}

Autor, D., Cho, D., Crane, L.D., Goldar, M., Lutz, B., Montes, J., Peterman, W.B., Ratner, D., Villar, D., Yildirmaz, A. An Evaluation of the Paycheck Protection Program Using Administrative Payroll Microdata. http://economics.mit.edu/files/20094

Barkik, A., Bertrand,M., Cullen, Z., Glaeser, E., Luca, M., Stanton, C (May, 2020). The Impact of COVID-19 on Small Business Outcomes and Expectations. (SSRN Working Paper 20-102), Social Science Research Network. https://papers.ssrn.com/sol3/Papers.cfm?abstract id=3570896

Chetty, R., Friedman, J., Hendren, N., Stepner, M., (September 2020). The Economic Impacts of Covid-19: Evidence from a New Pubic Database Built from Private Sector Data. (NBER Working Paper 27431), National Bureau of Economic Research. https://www.nber.org/papers/w27431

U.S. Small Business Administration, Office of Advocacy. (December 2018). Small business GDP 1988 - 2014 [Press Release]. https://advocacy.sba.gov/2018/12/19/advocacy-releases-small-business-gdp-1998-2014/ 
U.S. Small Business Administration, Office of Advocacy. (January 2019). Small Businesses Generate 44 Percent of U.S Economic Activity. [Press Release]. https://advocacy.sba.gov/2019/01/30/small-businesses-generate-44-percentof-u-s-economic-activity/

U.S. Small Business Administration, Office of Advocacy (June 2020). Paycheck Protection Program Report. [Press Release]. https://www.sba.gov/document/report-paycheck-protection-program-report-through-june-30-2020

U.S. Bureau of Labor Statistics (June 2020). The Employment Situation- May 2020 [Press Release].

https://www.bls.gov/news.release/archives/empsit 06052020.pdf

Center for Disease Control (March 2020). United States Coronavirus (COVID-19 Death Toll Surpasses 100,000 [Press Release] https://www.cdc.gov/media/releases/2020/s0528-coronavirus-death-toll.html 